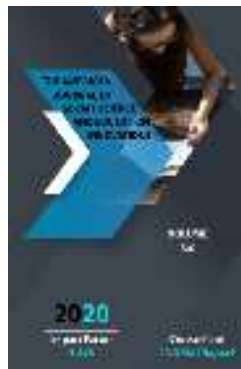

\section{Use Of Collaborative Learning Strategies In The Formation Of Skills Of Philology Students Of Pedagogical Universities}

\author{
Aripova Malika Ganisherovna \\ Navoi State Pedagogical Institute, Lecturer Department Of Russian Language And Literature, \\ Uzbekistan
}

Journal Website: http://usajournalshub.c om/index,php/tajssei

Copyright: Original content from this work may be used under the terms of the creative commons attributes 4.0 licence.

\title{
ABSTRACT
}

The article discusses the positive result of using strategies for collaborative teaching of students of philology. The use of collaborative learning in the classroom for the discipline "History of Russian Literature" in pedagogical universities. In the lesson on the topic: Genre of realistic poem in the works of A.S. Pushkin. The connection between "Poltava" by A. Pushkin and the poem "Voinarovsky" by K. Ryleev.

\section{KEYWORDS}

Method, collaborative environment, collaborative project, training, literature, innovation, analysis, critical thinking, pedagogical technologies, occupation model.

\section{INTRODUCTION}

The twenty-first century has brought humanity, along with powerful technologies, the development of all spheres of activity, and a global problem called the pandemic. The spread of COVID-19 virus infection around the world has forced humanity to look at life in a new way and make its own adjustments. The adjustments affected not only industry, private 
business, healthcare, tourism, but also education. The education system is a reference point for the development of all spheres of human activity.

The education system of the Republic of Uzbekistan was forced to switch to distance learning. Higher education institutions have created educational platforms. The platforms contain educational materials, video lessons, audio materials, and online educational resources. In the context of a pandemic and compliance with quarantine measures, students and teachers of educational institutions must adapt to this situation. Undoubtedly, the use of innovative technologies in the classroom has a positive result in the assimilation of new material, but how to convey the topic to the student at a distance, this question is now of concern to every teacher. Students are used to traditional methods of teaching, namely, listening to the teacher's lectures in person, asking questions about the topic, clarifying unclear points in the study. But distance learning is aimed at independent study of new material. Of course, a properly constructed lesson gives the student a step-by-step study of the proposed topic.

A special place in the construction of this type of activity is collaborative design. Collaborative pedagogical design is a preliminary development of the main details of the upcoming activities of students and teachers. The pedagogical process is the main object of design for the teacher. The educational process is a combination of components (factors) that contribute to the development of cooperation and friendly, trusting relationships between students and teachers.
Russian Russian language and literature, the discipline "History of Russian literature (the first half of the XIX century)", is studied in the IV semester, and the course is given a total of 156 hours, including 36 hours of lectures, 46 hours of seminars, and 74 hours of independent education.

The study of the module "The Life and work of Alexander Pushkin" takes only 30 hours: 10 hours of lectures, 8 hours of seminars and 12 hours of independent education. Using the method of a collaborative project on the topic: the Genre of a realistic poem in the works of Alexander Pushkin. Connection of "Poltava" by A. S. Pushkin and the poem "voynarovsky" by K. Ryleev. The study of this topic is given 2 hours.

The teacher gives tasks for preparing the project.

1. Students should read Pushkin's poem "Poltava".

2. To learn the history of creation.

3. Historical events in the work.

4. Historical figures in the work.

5. Read K. F. Ryleev's poem "voynarovsky".

6. Historical connection of the poems "Poltava" and "voynarovsky".

7. Fill in the concept table.

8. Prepare a project. 
The American Journal of Social Science and Education Innovations (ISSN - 2689-100x)

Published: August 23, 2020 | Pages: 242-245

Doi: https://doi.org/10.37547/tajssei/Volume02Issue08-39

\begin{tabular}{|l|l|l|l|}
\hline \multicolumn{1}{|c|}{$\begin{array}{c}\text { Heroes of the } \\
\text { poems }\end{array}$} & $\begin{array}{c}\text { "Poltava" by A. S. } \\
\text { Pushkin }\end{array}$ & $\begin{array}{c}\text { "Voynarovsky" by } \\
\text { K. F. Ryleev }\end{array}$ & Distinctive features \\
\hline $\begin{array}{l}\text { Mazepa, Ivan } \\
\text { Stepanovich- }\end{array}$ & & & \\
\hline $\begin{array}{l}\text { Khocubey, Vasyl } \\
\text { Leontyevich- } \\
\text { Ukrainian General } \\
\text { judge }\end{array}$ & & & \\
\hline $\begin{array}{l}\text { Love-Kochubey's } \\
\text { wife Maria }\end{array}$ & & & \\
\hline $\begin{array}{l}\text { Kochubey - their } \\
\text { daughter (the } \\
\text { prototype was the } \\
\text { daughter of V. L. } \\
\text { Kochubey Matrena) }\end{array}$ & & & \\
\hline $\begin{array}{l}\text { Peter the Great - } \\
\text { Russian Tsar }\end{array}$ & & & \\
\hline $\begin{array}{l}\text { Charles XII-Swedish } \\
\text { king }\end{array}$ & & & \\
\hline Voynarovsky & & & \\
\hline Miller is a historian & & & \\
\hline
\end{tabular}

After submitting the project, participants are invited to analyze the completed lessons, highlighting what they managed and failed to do, formulate questions that appeared, as well as suggestions for improving the activity. Each participant enters the results of the reflection in an individual card.

Individual reflection card for the "My offer" method

\begin{tabular}{|l|l|}
\hline "+"I MANAGED TO: & "-" I COULDN'T DO IT: \\
\hline "? "I HAVE SOME QUESTIONS: & "! "MY OFFER: \\
\hline
\end{tabular}


Doi: https://doi.org/10.37547/tajssei/Volume02Issue08-39

This method allows you to get the results of reflection of educational activities in a detailed verbal form. Analysis of the results of this method allows the teacher to correct the content and methods of students ' activities.

\section{REFERENCES}

1. Guzeyev V. V. Planning of educational results and educational technology. Moscow: National education, 2010

2. Zakharova I. G. Information technologies in education. M, 2011

3. Interactive teaching methods. (Electronic resource).

4. Methods of learning. (Electronic resource). 